\title{
Building Resilient Tourism SMMEs amidst and post COVID-19 Pandemic: A Case of South Coast, KwaZulu-Natal, South Africa
}

\author{
Thembinkosi Keith Gumede ${ }^{1}$ \\ ${ }^{1}$ Department of Recreation and Tourism, Faculty of Arts, University of Zululand, South Africa \\ Correspondence: Thembinkosi Keith Gumede, Department of Recreation and Tourism, Faculty of Arts, University \\ of Zululand, KwaDlangezwa 3886, South Africa. E-mail: GumedeTK@unizulu.ac.za/tkgumede8@gmail.com
}

Received: November 10, 2021

Accepted: January 10, 2022

Online Published: March 2, 2022

doi:10.5539/ijbm.v17n4p29

URL: https://doi.org/10.5539/ijbm.v17n4p29

\begin{abstract}
The paper explores measures adopted by the South African government alongside small business sector to sustain tourism SMMEs amidst COVID-19 pandemic. The data were collected from respondents who were purposefully sampled and interviewed using face-to-face mode of enquiry. The data were analysed through content analysis and the emerged findings indicate that tourism SMMEs had been adversely affected by COVID-19 pandemic and resultant lockdown restrictions. Numerous tourism SMMEs had to cease operations, face potential bankruptcy, negotiate pay-cuts and retrench some of the personnel staff. However, certain measures had been adopted by the government alongside small business sector to demonstrate resilience to lockdown restrictions as the pandemic continuously mutates from one variant to the other.
\end{abstract}

Keywords: resilience, tourism SMMEs, COVID-19 pandemic, lockdown restrictions, KwaZulu-Natal

\section{Introduction}

Tourism sector has been promulgated as the world's largest industry, a strategic priority and a vehicle through which South Africa's myriad socio-economic challenges can be alleviated (Ramukumba, 2017). The sector's contribution to the country's gross domestic product [GDP] constituted about 9.3\%, equivalent to R273.2 billion in 2019 and had created approximately 1.5 million job opportunities during the same year (World Travel and Tourism Council [WTTC], 2020). The sector has been considered as South Africa's 'new gold' resulting from its significant contribution towards the country's economy and a mainstay of the country's small, medium and micro enterprises [SMMEs] (Odeku, 2020). Accordingly, the sector has been regarded as the lifeblood for numerous SMMEs with their operations considered to have been playing an essential role in the country's economic growth (Statistics South Africa [StatsSA], 2019; Odeku, 2020). A report released by the Department of Trade and Industry [DTI] indicated that tourism SMMEs contributed about 52 to $57 \%$ towards the country's GDP and about $61 \%$ to the country's total employment in 2012 (DTI, 2012). Through the accommodation and hospitality sub-sets, the sector accounts for approximately $16 \%$ towards the country's tourism industry's total output and $19 \%$ towards the industry's total employment (StatsSA, 2019). Nonetheless, as a component of modern tourism industry, tourism SMMEs have been considered to be highly susceptible to operational disruptions resulting from well-known and unknown hazardous global phenomena that may negatively impact on tourism flows (Speakman \& Sharpley, 2012; Ritchie \& Jiang, 2019; Rogerson \& Rogerson, 2020). These phenomena include, but not confined to, natural disasters, political turmoil, economic downturns, epidemic and pandemic diseases. Although previous pandemic outbreaks and health crisis such as SARS, H1N1 and Ebola have had adverse effects on the tourism economy and tourist travel behaviour, the global outbreak of novel coronavirus, popularly known as COVID-19, has had a devastating cross-sectorial economic impact the world over and thus became an international crisis and global media event (Gössling, Scott \& Hall, 2020; United Nations World Tourism Organization [UNWTO], 2020). Undesirably, pandemic diseases may engender prolonged upheaval as their impact persists even during postoutbreaks (Bae \& Chang, 2021). The South African tourism SMMEs sector has not been exempted from being victimized by the rampant spread of the pandemic and subsequent lockdown restrictions (Department of Small Business Development [DSBD], 2020). As a subject of considerable psychosocial and socio-economic dimensions, COVID-19 has become a dominant feature in recent tourism scholarship (Rogerson \& Rogerson, 2021; Rogerson, Lekgau, Mashapa \& Rogerson, 2021; Bae \& Chang, 2021; Neuburger \& Egger, 2021; Dube, Nhamo \& Chikodzi, 2021; Ntounis, Parker, Skinner, Steadman \& Warnaby, 2021), just to mention a few. Nonetheless, there is no 
empirical research that has thus far been conducted on the impact of COVID-19 on South Africa's tourism SMMEs with specific focus on responses to demonstrate resilience to the strain posed by the pandemic on the business operations. Gregurec, Tomičić Furjan and Tomicic-Pupek (2021:2) acknowledge that "focusing on how SMMEs respond to challenges posed by COVID-19 is fundamental, especially within the context of a service sector that has been severely impacted by lockdown restrictions'. In line with this literary background, the paper aims to explore the measures adopted by the government alongside small business sector to sustain tourism SMMEs amidst COVID-19 pandemic. Linked to the aim of the study, the paper sought to achieve the following objectives: i) to determine the effects of COVID-19 on tourism SMMEs within the study area; and ii) to ascertain the measures adopted by tourism SMMEs to demonstrate resilience amidst COVID-19 pandemic within the study area. Based on the objectives, the findings of the study would provide insight regarding tourism SMMEs' level preparedness to sustain business operations during the outbreak of public health crisis such as COVID-19 pandemic.

\section{Theoretical Underpinning}

This paper views 'tourism SMMEs' as a concept that is deeply entrenched within the business theory. According to the theory, there are three considerations that should be taken into account by business organizations as they have direct bearing on their operational framework (Drucker, 1994), and they are: (1) assumptions relating to the organizational environment, (2) assumptions relating to the accomplishment of the organizational mission, and (3) assumptions relating to the competencies and resources enabling the fulfilment of the organizational mission. Maritz, Perényi, De Waal and Buck (2020) caution about the importance of review and rethought of the relevance or appropriateness of any theory under certain unprecedented circumstances including its success or failure. Equally, business theory makes provision for business organizations to reconsider their key assumptions in cases where unprecedented business environment arises (Daly \& Walsh, 2010). Similar to the point of view upheld by Gregurec et al. (2021: 1), we argue that the environment within which tourism SMMEs operate has completely changed from being 'normal sectorial environment characterized by positive economic prospects' into a 'new normal environment' characterized by uncertain economic prospects. By virtue of hierarchical entitlement, top management possesses the capacity to lead in defining key aspects guiding the operations of business enterprises including their culture and strategic intent (Jovanov Marjanova \& Sofijanova, 2014). The authors uphold that aspirations of a business enterprise should be underpinned by a strategic intent communicated through its vision, mission and goals' statement. A mission statement serves as a means by which a certain image of the underlying intent of the existence of a business enterprise is projected (Campbell, 1997). A mission statement defines important matters including goals and approaches by which such could be achieved (Rigby, 2011). Basically, the development of a mission statement arises from the objectives that could be achieved with it (Campbell \& Yueng, 1991). These objectives include, but not limited to, achieving higher performance, striking a balance between conflicting interests and beliefs held by different groups of stakeholders, and decisiveness and consistency regarding allocation of resources (Jovanov Marjanova \& Sofijanova, 2014). Against this background, the paper considers business theory to be pertinent to the researched phenomenon hence, it denotes flexibility and responsiveness in dealing with a continuous changing environment under which tourism SMMEs operate due to unprecedented changes in demography, socio-economy, technology and tourists' demands (Mariani \& Giorgio, 2017; Haarhoff \& De Klerk, 2019).

\section{Literature Review}

\subsection{Overview of South Africa's Tourism SMMEs}

Based on their potential for facilitating economic growth, income diversification and sustainable development (Rogerson, 2005; Mshenga \& Richardson, 2013), tourism SMMEs remain an essential issue among scholars, policy analysts and planners involved in the South African tourism industry (Hlengwa \& Thusi, 2018). There had been an increased emergence of SMMEs in the country dominated by previously disadvantaged Black entrepreneurs post-1994. The eruption of SMMEs is believed to have been triggered by the country's reintegration into the global economy and subsequent hosting of major events such as World Summit on Sustainable Development in August 2002 and prestigious FIFA World Cup in 2010 (United Nations, 2002; Rogerson, 2005; Bob \& Potgieter, 2013). As such, numerous government initiatives and development policies that promote establishment and sustainability of SMMEs as one of the essential mechanisms through which the country's Vision 2030 could be realized had been put into place (Department of Environmental Affairs and Tourism [DEAT], 2004). These include: enactment of the 1995 White Paper on Small Business, National Small Business Development Act of 1996, 1996 Tourism White Paper, National Development Plan [NDP] and Disaster Management Act, 2002 (Act No. 57 of 2002) (Rogerson, 2005; DSBD, 2020). Based on the set targets, Vision 2030 envisaged that at least 11 million job opportunities would have been created by 2030, of which a significant percentage (about $90 \%$ ) is expected to have been generated from the SMMEs sector (Department of Economic Development, 2011; National 
Planning Commission, 2011). As a further commitment to support promotion and development of SMMEs, the country's government established a standalone Ministry of Small Businesses or Department of Small Business Development [DSBD] in 2014. The DSBD had been mandated to facilitate the development and growth of small businesses and cooperatives such that these contribute toward the country's inclusive and shared economic growth (DSBD, 2014; Greve, 2014). Despite these government's efforts, review of literature (Kaplan, 2004; Nemasetoni \& Rogerson, 2005; Rogerson, 2005; DTI, 2005; Rogerson \& Rogerson, 2020) indicates that there are numerous challenges faced by the country's tourism SMMEs that remain unresolved to date. These include, but not confined to, poor marketing strategies, incompetent and unqualified human resource, poor infrastructure, bureaucracy as well as biased financial support and access to market. However, the extent of the effects resulting from these challenges might not have been proportionate amongst tourism SMMEs as the country's travel and tourism industry is characterized by a three-tiered hierarchy of enterprises (Rogerson, 2005). At the top level, there is established elite group of enterprises responsible for, among other things, provisioning of major travel and tour agencies, transport, accommodation, culinary and recreation facilities. These are followed by a group of established and predominantly white-owned enterprises that offer different services such as travel and tourism, accommodation and culinary and game farming. At the bottom level, there is emerging Black-owned enterprises comprising few formal micro-enterprises and numerous informal enterprises.

\subsection{Impact of COVID-19 on South Africa's Tourism SMMEs}

As one of the world's prominent tourism destinations and African continent's biggest economies, South Africa attracts many international citizens who travel frequently to the country, especially for business and visiting friends and relatives [VFR] purposes. However, tourism flows towards the country have been adversely disrupted due to the global outbreak of COVID-19 and resultant stringent lockdown measures. The pandemic is believed to have hit South Africa towards the end of 2019 or at the beginning of 2020. The first COVID-19 positive case in South Africa as reported on 5 March 2020, was of a 38-year-old male who had recently travelled to the country from Italy (Rogerson \& Rogerson, 2020). This was followed by a shocking report within twelve days indicating that there were about 1170 confirmed cases and one recorded COVID-19-related death (Rogan \& Skinner, 2020). On 1 August 2020, the country's Minister of Health at the time, Dr Zweli Mkhize, made a shocking announcement that more than 500000 cases of COVID-19 had already been confirmed. Having taken potential threats to both the lives of the citizens and the country's economy into consideration resulting from the rampant spread of COVID19 , the country's government, informed by rigorous consultation with relevant bodies lead by the National Coronavirus Command Council [NCCC], declared a 'National State of Disaster' and immediate inception of three weeks lockdown measures with effect from 27 March 2020 (Arndt, Davis, Gabriel, Harris, Makrelov, Modise, Robinson, Simbanegavi, van Seventer \& Anderson, 2020). These were considered as harshest lockdown measures compared to those implemented in other parts of the world as citizens were prohibited from going out of their households or travel unless they wanted to purchase food, sought medical care or accessing social grants (Rogan \& Skinner, 2020). Unfortunately, drastic measures necessary to combat the rapid spread of COVID-19 demanded several legislative actions that inevitably hindered the societal normal functioning (Al-Fadly, 2020). As had been the case with the global economies, tourism SMMEs had also been severely affected by lockdown measures as the vast majority of these enterprises had to cease operations with immediate effect as they could no longer conduct their normal business activities for the fear of further spreading the pandemic through person-to-person mode of transmission. Ceasing business operations triggered a domino effect of issues chief of which was job loss and subsequent psychosocial adverse effect on entrepreneurs and employees (Al-Fadly, 2020). Almost, all enterprises under the ambit of hospitality and accommodation sector went through a similar predicament as they had to face potential bankruptcy, negotiate pay-cuts, effecting mass layoffs and ultimate closure (Joubert, 2020; Bartik, Bertrand, Cullen, Glaeser, Luca \& Stanton, 2020; Ikwegbue, Enaifoghe, Maduku \& Agwuna, 2021). Hospitality and accommodation are considered to be interlocked sub-sectors under the ambit of tourism SMMEs and amongst the world's leading labour intensive sub-sectors (Bureau for Economic Research, 2016). However, the development and sustainability of these sub-sectors depend largely on supply chain networks which had also been broken by the COVID-19 contagion (Al-Fadly, 2020). Consequently, the suppliers, tourism SMMEs, employees as well as consumers had been certainly disrupted into a sinking whirlpool (Baldwin \& Mauro, 2020). Equally, the disruption in the South Africa's tourism SMMEs operations prompted extensive anxiety to the vast majority of tourism business fraternity. Following rigorous situational analysis on infection rates and death toll associated with COVID-19, the South Africa's government made a decision to move the country from the strictest alert levels (5 and 4) characterized by full lockdown and high restrictions to alert level 3 . The latter is characterized by moderate restrictions based upon both moderate spread of COVID-19 and health system readiness. The country's long-term planning response toward COVID-19 crisis for the phased withdrawal of lockdown restrictions was announced on the $23^{\text {rd }}$ of April 2020 and had been informed by a report prepared for The Presidency. A report serves as a 
governance framework for a 'risk-adjusted strategy' for economic activity which is based on different levels of alert and adapted to the epidemiological threats associated with COVID-19 outbreak (Rogerson \& Rogerson, 2020). Despite the changes effected under alert level 3 which permitted other sectors to resume normal operations, tourism and its dependent sectors including SMMEs had to proceed with operating under 'new normal' conditions due to the fact that the sector is not considered as an essential service within the country (Bama \& Nyikana, 2021). Gregurec et al. (2021: 1) affirm that 'unlike other industries and business ventures that might have been prone to a certain degree of resilience, tourism SMMEs could neither endure the impact of the pandemic nor consider an alternative operating niche resulting from being exposed to what has become a new normal environment'. Mega events and indoor consumption of alcohol in hospitality facilities remained prohibited under alert level 3 which left many tourism SMMEs' owners no choice but to adapt to a peculiar business environment, finding ways of establishing their position amidst their employees, consumers and legislation. Accenture (2020) maintains that entrepreneurs need to juggle survival both in short-term and long-term as employees and communities try to function and perform, while struggling to cope with the status quo. Currently, the country has been moved to lockdown alert level 2 with effect from 12 September 2021 resulting from continuous decline in new COVID-19 infection cases. Severe restrictions had also been lifted which enabled tourism and related sectors to resume full operations under precaution measures and regulated operating hours in line with lockdown alert level 2 (South African Government, 2021).

\subsection{Resilience Amidst Pandemics and Epidemics}

By definition, resilience is as a process whereby a set of adaptive capacities is linked with a positive trajectory of functioning and adaption during post-business operations' interruption (Norris, Stevens, Pfefferbaum, Wyche \& Pfefferbaum, 2008). Borrowing from Alonso, Kok, Bressan, O'Shea, Sakellarios, Koresis, Solis and Santoni (2020), we define resilience in the context of tourism, as the industry's capability to implement necessary strategies for overcoming potential disruptions due to unprecedented crisis or disaster. In a nutshell, resilience means that the tourism industry has all necessary resources in place to enable resumption of normal operations after being disrupted by COVID-19 lockdown restrictions. Resilience can either take a form of 'a process' or 'an outcome' (Tylor, 2020). As a process, resilience refers to tourism industry's effort to effectively and efficiently apply necessary mechanisms to achieve a desired outcome. As an outcome, it refers to the tourism industry's ability to achieve a desired state. Applying necessary mechanisms and being able to achieve a desired outcome or state require continuous adjustment to the impact of COVID-19 lockdown restrictions and resultant crisis faced by the tourism industry by learning from the challenges and establishing new ideas of sustaining the industry amidst crisis (Ruiz-Martin, López-Paredes \& Wainer, 2018). Interestingly, literary trends indicate that many parts of the world have been able to demonstrate salience to different pandemics and epidemics. For example, Japan's hospitality and accommodation industry had been resilient to SARS in 2003 resulting from launching aggressive campaigns (Mao, Ding \& Lee, 2010). Korean hospitality industry had been able to minimize job losses amidst SARS through implementing crisis management strategies (Khan, Bibi, Lyu, Latif \& Lorenzo, 2021). Three West African countries (Guinea, Liberia and Sierra Leone) under the auspices of WHO had been resilient to Ebola Virus Disease (EVD) by implementing the Ebola Response Roadmap (WHO, 2015). The sub-Saharan and many African countries have been resilient to HIV/AIDS pandemic by implementing Anti-Retroviral Therapy [ART] roll-out program (de Paoli, Mills, \& Grønningsaeter, 2012). It is therefore, apparent that tourism and related sectors through public, private sectors partnership [PPP] have the capacity to deal effectively with COVID-19 and its impacts to maintain and stabilize sectors' normal operations. This could assist in facilitating flexibility and diversity necessary for innovation and further development within the tourism industry and its value chain (Buultjens, Ratnayake, \& Gnanapala, 2017). In line with the above, Jamal and Budke (2020) concur that there is a great need for stakeholder collaboration when planning for and managing resilience as there is likelihood for pandemics to become a common feature of the tourism industry.

\section{Study Area}

The study focused on the SMMEs that fall within the ambit of accommodation and hospitality operating within the Ray Nkonyeni Local Municipality under Ugu District in KwaZulu-Natal, South Africa. There is a variety of popular entertainment and marine events that have been regularly hosted within the municipality on annual basis (Celliers, Rosendo, Costa, Ojwang, Carmona \& Obura, 2019). These include: Margate Air Show, Lions South Coast Show, uGu Sardine Run [USRF] and Ugu Jazz Festivals (Ray Nkonyeni Municipality, 2016/17). Over the years, there has been numerous tourists (both domestic and international) who flock towards the municipality to participate in or attend entertainment events (Myeza, Mason \& Peddemors, 2010; Celliers et al., 2019). Apart from event organizers, local entrepreneurs who own SMMEs that offer accommodation and culinary services have been significantly benefiting from these events (Myeza et al., 2010). The events therefore, have been significantly 
contributing towards the socio-economy of the local communities as they enable locals to participate in localbased tourism activities (Ramukumba, 2019). The geographical position of the study area with one of its prominent ecotourism sites (Oribi Gorge Nature Reserve) is shown in Figure 1 below.

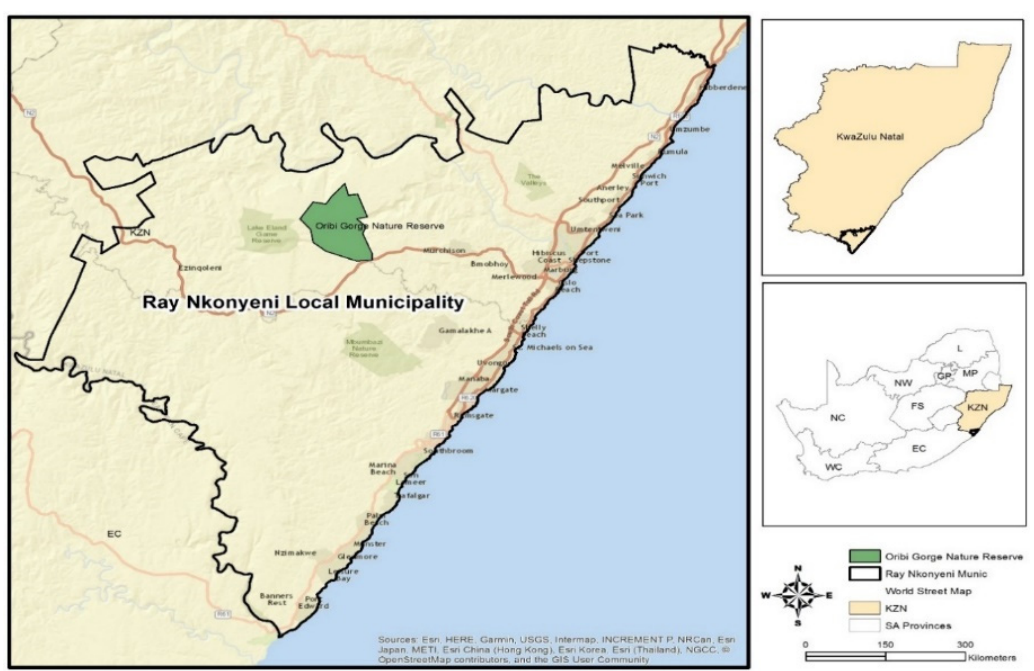

Figure 1. Geographical location of the study area

\section{Research Design, Collection and Analysis of Data}

The study sought to explore how a particular social group experienced the world. This was done through authors' explanation of the phenomenon as it occurred within a specific social context which in this study, refers to tourism SMMEs' owners affected by COVID-19 pandemic. This explanation is meant to provide the potential reader with a visualization of how a specific area of social world functions in instances whereby individuals hold a subjective worldview, and to collate a collective view of the researched phenomenon. Against this background, the study subscribed to interpretivism philosophical foundation. The paradigm had been adopted on the basis that it considers subjective interpretation of human beings and their perception of the world as a fundamental basis of understanding social phenomena (Kelliher, 2005). Telephone appointments were made to set dates and time and to choose places that were deemed suitable for conducting interviews. In order to yield better results despite lockdown restrictions, the investigation setting was diversified such that the study covered accommodation and culinary facilities in the proximity (Paddock, Marburg and Port Shepstone) of one of the prominent nature-based areas (Oribi Gorge Nature Reserve) and those located adjacent to Port Edward and Hibberdene (where the USRF had been held). The researcher employed an inductive approach through unstructured in-depth interviews. In-depth interviews are considered to be the most appropriate data collection format in cases where the researcher intends to solicit the participants' perception of the studied phenomenon (Cheng, Jin \& Wong, 2014), in this case, the impact of COVID19 on tourism SMMEs. Interview schedules were used to collect data through face-to-face interviews from 25 tourism SMMEs' owners who were purposefully sampled. Creswell (2014) affirms that the appropriate sample size for phenomenological research ranges from 5 to 25 . The chosen sample size was deemed appropriate hence, the maximum number of the participants was determined by a saturation point. Bradley, Curry and Devers (2007) describe a saturation point as a level of qualitative data collection where there is no new information that emerges from further investigation. Smith (2010) upholds that the researcher is able to assess, during the interviews, if further data collection is necessary. The respondents' willingness to express how their business had been impacted by COVID-19 pandemic served as the basis for the research trustworthiness. Prior to data collection process, each participant consented to voluntary participate in the study by expressing their genuine feelings regarding the researched phenomenon. The responses that emerged from the interviews were recorded through a recording device and were transcribed verbatim at a later stage for analysis purposes. Transcriptions of the responses meant that the spoken words had to be converted to written words in order to facilitate analysis immediately after the collection of data (Sutton \& Austin, 2015). The study employed content analysis technique which enabled the researcher to sift common threads from the responses that were recorded during data collection and transcribed verbatim. Field notes that were compiled during data collection served as useful complementary source of information in facilitating data analysis. Compiling field notes had been useful in this paper as the gap in time 
between interviews, transcription and coding can result into memory bias with regard to non-verbal or environmental context issues that may have had an effect on interpretation of the results.

Table 1. Socio-economic demographic attributes of the respondents $(\mathrm{N}=25)$

\begin{tabular}{|c|c|c|c|}
\hline \multicolumn{2}{|r|}{ Variable } & Frequency $(\mathrm{N})$ & Percentage (\%) \\
\hline \multirow[t]{3}{*}{ Gender } & Male & 21 & 84 \\
\hline & Female & 4 & 16 \\
\hline & Total & 25 & 100 \\
\hline \multirow[t]{6}{*}{ Age } & $18-28$ & 3 & 12 \\
\hline & $29-39$ & 11 & 44 \\
\hline & $40-50$ & 4 & 16 \\
\hline & $51-61$ & 5 & 20 \\
\hline & $62+$ & 2 & 8 \\
\hline & Total & 25 & 100 \\
\hline \multirow[t]{9}{*}{ Education } & No education & - & - \\
\hline & Primary & 2 & 8 \\
\hline & Secondary & 12 & 48 \\
\hline & Matric & 8 & 32 \\
\hline & Post matric training/certificate & 2 & 8 \\
\hline & Diploma & 1 & 4 \\
\hline & Degree & - & - \\
\hline & Postgraduate training/certificate & - & - \\
\hline & Total & 25 & 100 \\
\hline \multirow[t]{8}{*}{ Monthly revenue } & No revenue & - & - \\
\hline & $<$ R1 000 & 10 & 33 \\
\hline & R1 000-R5 000 & 15 & 67 \\
\hline & R5 001-R10 000 & - & - \\
\hline & R10 001-R15 000 & - & - \\
\hline & R15 001-R20 000 & - & - \\
\hline & $>\mathrm{R} 20000$ & - & - \\
\hline & Total & 25 & 100 \\
\hline
\end{tabular}

As shown in Table 1, there were 25 participants ( 21 males and 4 females, aged between 18 and 62 years and above, who owned their tourism-related enterprises and directly affected by COVID-19) who participated in the study. The findings in terms of the socio-economic demographics indicate male dominance (84\%) in terms of participation in the study as opposed to females (16\%). Based on the researcher's observation during data collection, the nature of the results may have been influenced by the fact that males dominated females in business ownership within the study area. In terms of participation in the study, the majority (44\%) was in the age category of 29 to 39 years compared to other age categories ( 51 to 61 years at $20 \%, 40$ to 50 years at $16 \%, 18$ to 28 years at $12 \%$, and 62 and above years at $8 \%$ ). These variations in terms of response rate might have been attributed to the fact that most people between the ages of 29 and 39 years are not employed (StatsSA, 2021), and are therefore engaged in business sector to make a living. Soliciting education level of the participants was considered important as it might determine the participants' understanding and awareness in terms of proper management of business enterprises (Aminrad, Sayed-Zakariya, Samad-Hadi \& Sakari, 2013). The findings indicate that the majority (44\%) of the participants had secondary education compared to other (post-matric training/certificate at $24 \%$, matric at $20 \%$, primary at $8 \%$, and diploma at $4 \%$ ) education categories. This finding indicates sufficient capability of SMMEs' owners for managing their businesses as the majority of them had acquired secondary education, while a moderate proportion had gone further to acquire post-matric education. As a result of lockdown restrictions and potential effects on revenue generation capability, determining the tourism SMMEs' monthly revenue remained essential towards achieving the aim of the study. The findings reveal that the maximum monthly revenue generation capability of the majority $(67 \%)$ ranged between R1, 000 and R5, 000 . The other proportion (33\%) managed to generate only R1000 and below a month. This may be an indication of how lockdown restrictions might have adversely impacted on normal operations of tourism SMMEs and the ability to pay for fixed and variable costs. The first objective of the study sought to determine the effects of COVID-19 on tourism SMMEs. The findings show a mutual feeling held by the participants as they explained how the pandemic and resultant lockdown restrictions had adversely impacted on their businesses' normal operations and own psychosocial wellbeing.

I became astonished when I heard the president of the Republic (President Cyril Ramaphosa) on 27 March 2020 making an order that all business activities except supermarkets, healthcare facilities and social grants pay points were to cease operations with an immediate effect. The order triggered a start of unprecedented downfall of the country's tourism industry which subsequently imposed a similar predicament on our hospitality and 
accommodation businesses. The president made an order that social gatherings, indoor and outdoor events, and travelling in and outside the country were prohibited. I did not know where to start with telling my family and employees that we would be out of jobs with effect from the next day (28 March 2020). Although we were promised financial support from the government to sustain our livelihoods while our businesses were closed down, the criteria for qualifying was absolutely exclusive and unfair as we had to have our tax payments up-to-date before we could qualify for the financial support. Consequently, most of us did not qualify and had to suffer awful consequences. After a long period of suffering and despair, the government, under lockdown alert level 3, had allowed us to resume business operations under strict and future uncertain environment. Out of five employees that I had to retrench during lockdown alert levels 5 and 4, I had been able to reinstate only one during lockdown alert level 3 resulting from reduced working hours and future uncertainty. (Accommodation and culinary facility owner, 38, Male, Marburg)

The same sentiment was shared by other counterparts as they had to echo:

My business had been the only source of income for my family and seven employees. Closing our businesses after having been ordered by the government due to rapid spread of COVID-19 had been a big blow to ourselves. The process of the financial support from the government has been very slow and had involved lots of technicalities. Consequently, I became discouraged to follow tedious procedures through which I could have accessed government support grant or a loan and decided to stay at home to protect myself and my family from contracting the virus. Despite recent easing of certain lockdown restrictions by the government which afforded us an opportunity to resume our business operations, the business environment is no longer the same hence normal business hours have been reduced while on-site food and beverage consumption have been prohibited. I therefore, had to make unfavourable adjustments which include: downsizing my staff from seven to two employees and relinquishing my important possessions due to unaffordability and future uncertainty. (Accommodation and culinary facility owner, 36, Port Shepstone).

It has been very unfortunate that hosting events through which we had been sustaining our businesses' and families' livelihoods has been dismissed as mega events and social gathering have been declared by the government as 'COVID-19 super-spreaders'. Our businesses have been contributing towards the country's socio-economy and GDP through income tax and value added tax paid by ourselves and our employees. Despite, the government has failed us as the procedure for accessing support grants for sustaining our businesses has been cumbersome such that many of us became discouraged after having started with the claiming process. However, there is a lot that one has learned from the impact that COVID-19 outbreak and subsequent lockdown restrictions have had in our lives. These have equipped us with feature preparedness when such tragic events occur. For example, one has taken into consideration the importance of having our business ensured, fully registered with relevant agencies and updating income tax payments. (Accommodation and culinary facility owner, 50, Port Edward).

We have been very much crippled by COVID-19 as many people have lost their jobs due to shutdown of business operations. Former employees including heads of households found themselves reliant on a meagre R350 COVID19 government relief fund for survival. Although we have a vaccination process underway, the pandemic proves to be capable of being in our midst for an unprecedented and longer period. Our sector (hospitality and accommodation) is highly prone to succumb to typical ravaging events. Our country does not have enough resources to overcome the socio-economic impact of COVID-19 hence it had been already in crisis with regard to abject poverty, unemployment, income inequality and poor service delivery long before COVID-19 outbreak invade its shores. Frustration from citizens is becoming more intense and had forced them to engage in antisocial incidents such as the recent social unrests and subsequent looting spree that took place in July this year (2021). (Accommodation and culinary facility owner, 44, Hibberdene).

\section{Discussion, Conclusions and Recommendation}

The paper aimed to explore the measures adopted by the government alongside small business sector to sustain tourism SMMEs amidst COVID-19 pandemic. The key findings that emerged from the respondents' responses indicate that COVID-19 has had a ravaging impact on the tourism SMMEs within the study area as both owners and employees had to survive without income due to business shutdown and job losses. Equally, South Africa experienced the highest unemployment rate during the pandemic. According to the findings of the Quarterly Labour Force Survey [QLFS], the country has hit the ever highest record (34.4\%) of unemployment rate in the world since the inception of QLFS in 2008 (StatsSA, 2021). Importantly, the job loss from the tourism SMMEs sector has also contributed to the country's recent unemployment rate. This finding aligns with that of Joubert (2020); Bartik et al. (2020); Ikwegbue et al. (2021). The outbreak as AHLA (2020) acknowledges, has engendered uncertainty and despair amongst tourism, supply chain and related sectors. Possibly, the disquiet has been triggered 
by anticipated persistence of COVID-19 as it continuously mutating from one variant to the other. The findings both from the literature and survey show that government interventions to sustain tourism SMMEs' operations in the wake of the pandemic had not been efficient and effective. Against this backdrop, this paper holds a similar sentiment with Khan et al. (2021: 962) in viewing COVID-19 pandemic as 'an ultimate test for the business world'. Nevertheless, literary (Mao et al., 2010; Khan et al., 2021; WHO, 2015; de Paoli et al., 2012) trends indicate that many parts of the world including African continent successfully have demonstrated resilience to different pandemics and epidemics. Moreover, it is generally believed that resilience to economic and life threatening pandemics could be achieved through collaborative planning and management by different stakeholders (Jamal \& Budke, 2020). Interestingly, the study found that there are lessons learned by tourism SMMEs' owners from the impact of COVID-19. Experience is considered to be one of the factors that shape one's risk perception (Pennington-Grey, Schroeder \& Kaplanidou 2011) and it is one's risk perception that influences subsequent behaviour (Weinstein, 1998). In line with Brewer and Fazekas (2007) viewpoint, the paper considers susceptibility to the impact of COVID-19 pandemic severity as a perceived risk by which tourism SMMEs' behavioural change is necessitated. Correspondingly, the findings indicate that there were several strides made by tourism SMMEs' owners in response to the strain posed by COVID-19 on normal business operations, and these include strengthening levels of readiness should similar disastrous crisis occur in future. The strides taken by the South African government to facilitate resilience include: moving the country from lockdown alert level 3 (with effect from 25 July 2021 and amended on 30 July 2021) to lockdown alert level 2 (with effect from 12 September 2021). This meant that more lockdown restrictions are being eased day-by-day in an attempt to resuscitate the country's economy (South African Government, 2021). Severe restrictions had been lifted which enabled most country's economic sectors' operations under regulated operating hours including tourism and related businesses to be reopened while strict social distancing, hand sanitizing, and regular wearing of face masks are still to be adhered (South African Government, 2021). These adjustments had been attributed to continuous decline in new COVID19 infection cases probably resulting from: (1) citizens' enhanced behavioural responsiveness to the pandemic (Kollamparambil \& Oyenubi, 2021), and (2) citizens' positive response to vaccination roll-out since its inception on the $17^{\text {th }}$ of February 2021 (Daily Maverick, 2021). The majority of the inhabitants has been demonstrating positive response to the government's call for all citizens to get vaccinated (Dzinamarira, Nachipo, Phiri \& Musuka, 2021). However, the country has been struggling with achieving herd immunity as a result of vaccination hesitancy and significant reduction regarding social distancing practice (Kollamparambil \& Oyenubi, 2021). Although the country's responsiveness and resilience to the impact of COVID-19 pandemic on the economic sector may not match those of big economies such as the United States of America (USA) in terms of relief funding (about $\$ 484$ billion) and Paycheck Protection Program (estimated at $\$ 310$ billion), a day-by-day economic recovery is expected. Based on the above findings coupled with literary standpoint, the following conclusions were drawn: (1) COVID19 has had a devastating impact on South Africa's tourism SMMEs as they had to adapt to the 'new normal' business operation condition characterized by future uncertainty, (2) Although had not been effective to serve the intended purpose, there are strategies in place for sustaining tourism SMMEs amidst COVID-19 pandemic and these include: stimulus fund grants and loan waivers, and (3) Government and business sector have responded to demonstrate resilience to the strain posed by COVID-19 pandemic on tourism SMMEs by, among other things, adhering to most of precaution measures, enforcing vaccination roll-out program, and lifting lockdown restrictions. Nevertheless, the paper recommends that more awareness and community outreach campaigns be undertaken to overcome vaccination hesitancy and facilitate citizens' adherence to COVID-19 precaution measures.

\section{Limitations}

Lockdown restrictions meant to combat a rapid spread of COVID-19 posed serious challenges upon smooth and normal data collection approaches, procedures and timelines. Consequently, the duration of data collection had to take longer than under normal conditions. This had been triggered mainly by the fact that the periods between the making of appointments and actual interviews had to be extended beyond the anticipated time due to withdrawals of some of the SMMEs' owners from participating in the study. This happened at the time when the world desperately sought to establish how COVID-19 had impacted people's normal lives.

\section{Acknowledgements}

This research was supported by the grant from the National Research Foundation [Grant no, UID: 120734].

\section{References}

Accenture COVID-19 Consumer Research. (2020). Connecting with changing customer habits: Impact on customers. Retrieved from https://www.accenture.com/mu-en/about/company/coronavirus-businesseconomic-impact

AHLA [American Hotel \& Lodging Association]. (2020). COVID-19 devastating hotel industry, low to zero hotel 
revenue driving unprecedented job loss. $\quad$ Retrieved from https:/www.ahla.com/sites/default/files/FACT\%20SHEET_COVID19\%20Impact\%20on\%0Hotel\%20Indus try_4.22.20_updated.pdf

Al-Fadly, A. (2020). Impact of COVID-19 on SMEs and employment. Entrepreneurship and Sustainability Issues, 8(2), 629-648. https://doi.org/10.9770/jesi.2020.8.2(38)

Alonso, A. D., Kok, S. K., Bressan, A., O’Shea, M., Sakellarios, N., Koresis, A., Solis, M. A. B., \& Santoni, L. J. (2020). COVID-19, aftermath, impacts, and hospitality firms: An international perspective. International Journal of Hospitality Management, 91, 102654. https://doi.org/10.1016/j.ijhm.2020.102654

Aminrad, Z., Sayed-Zakariya, S. Z. B., Samad-Hadi, A., \& Sakari, M. (2013). Relationship between awareness, knowledge and attitudes towards environmental education among secondary school students in Malaysia. World Applied Sciences Journal, 22(9), 1326-1333. https://doi.org/10.5829/idosi.wasj.2013.1326.1333

Arndt, C., Davis, R., Gabriel, S., Harris, L., Makrelov, K., Modise, B., Robinson, S., Simbanegavi, W., van Seventer, D., \& Anderson, L. (2020). Impact of Covid-19 on South African economy: An initial analysis. International Food Policy Research Institute, SA-TIED Working Paper 111. Retrieved fromhttps://satied.wider.unu.edu/sites/default/files/pdf/SA-TIED-WP-111.pdf

Bae, S. Y., \& Chang, P. J. (2021). The effect of Coronavirus diseases-19 (COVID-19) risk perception on behavioural intention towards 'untact' tourism in South Korea during the first wave of the pandemic (March 2020). Current Issues in Tourism, 24(7), 1017-1035. https://doi.org/10.1080/13683500.2020.1798895

Bagnera, S. M., \& Steinberg, M. (2020). Sanitized practices for human resources in a COVID-19 environment. Boston Hospitality Review. Retrieved from https://www.bu.edu/bhr/files/2020/04/Sanitized-Practices-forHuman-Resources-in-a-Covid-19-Environment-pdf

Baldwin, R., \& di Mauro, B.W. (2020). Economics in the time of COVID-19. A VoxEU.org. eBook, (Eds.). CEPR Press.

Bama, H.K.N., \& Nyikana, S. (2021). The effects of COVID-19 on future domestic travel intentions in South Africa: A stakeholder perspective. African Journal of Hospitality, Tourism and Leisure, 10(1), 179-193. https://doi.org/10.46222/ajhtl.19770720-94

Bartik, A. W., Bertrand, M., Cullen, Z., Glaeser, E. E., Luca, M., \& Stanton, C. (2020). The impact of COVID-19 on small business outcomes and expectations. PNAS, 117(30), 17656-17666. https://doi.org/10.1073/pnas.2006991117

BER [Bureau of Economic Research]. (2016). The small, medium and micro enterprise sector of South Africa. Retrieved from http://www.seda.org.za

Bob, U., \& Potgieter, C. (2013). Mega-events and tourism impacts: Foreign visitor perceptions of the 2010 FIFA World Cup in South Africa. Journal of Human Ecology, 43(1), 71-82. https://doi.org/10.1080/09709274.2013.11906613

Bradley, E. H., Curry, L. A., \& Devers, K. J. (2007). Qualitative data analysis for health services research: Developing taxonomy, themes, and theory. Health Services Research, 42(4), 1758-1772. https://doi.org/10.1111/j.1475-6773.2006.00684.x

Brewer, N. T., \& Fazekas, K. I. (2007). Predictors of HPV vaccine acceptability: A theory-informed, systematic review. Preventive Medicine, 45(2-3), 107-114. https://doi.org/10.1016/j.ypmed.2007.05.013

Brewer, N. T., Chapman, G. B., Gibbons, F. X., Gerrard, M., McCaul, K. D., \& Weinstein, N. D. (2007). Metaanalysis of the relationship between risk perception and health behavior: The example of vaccination. Health Psychology, 26(2), 136-145. https://doi.org/10.1037/0278-6133.26.2.136

Browne, A., St-Onge Ahmad, S., Beck, C. R., \& Nguyen-Van-Tam, J. S. (2016). The roles of transportation and transportation hubs in the propagation of influenza and coronaviruses: A systematic review. Journal of Travel Medicine, 23(1), 1-7. https://doi.org/10.1093/jtm/tav002

Buultjens, J., Ratnayake, I., \& Gnanapala, A. (2017). Sri Lankan tourism development and implications for resilience. In R. Butler (Ed.), Tourism and Resilience (pp. 83-95). Wallingford: CABI.

Campbell, A., \& Yeung, S. (1991). Creating a sense of mission. Long Range Planning, 24(4), 10-20. https://doi.org/10.1016/0024-6301(91)90002-6

Campbell, A. (1997). Mission Statements. Long Range Planning, 30(6), 931-933. https://doi.org/10.1016/S0024- 


\section{1(97)00084-8}

Celliers, L., Rosendo, S., Costa, M., Ojwang, L., Carmona, M., \& Obura, D. (2019). A capital approach for assessing local coastal governance. Ocean and Coastal Management, 183, 1-8. https://doi.org/10.1016/j.ocecoaman.2019.104996

Cheng, M., Jin, X., \& Wong, I. A. (2014). Ecotourism site in relation to tourist attitude and further behavioural changes. Current Issues in Tourism, 17(14), 303-311. https://doi.org/10.1080/13683500.2013.800030

Creswell, J.W. (2014). Research design: Qualitative, quantitative and mixed methods approaches (4th ed.). Thousand Oaks: Sage Publications.

Daily Maverick. (2021). South Africa to give first COVID-19 vaccine doses to president and health workers. Retrieved from https:/www.dailymaverick.co.za/article/2021-02-17-south-africa-to-give-first-covid-19vaccine-doses-to-president-health-workers.pdf

Daly, P., \& Walsh, J. S. (2010). Drucker's theory of the business and organisations: Challenging business assumptions. Management Decision, 48, 500-511. https://doi.org/10.1108/00251741011041319

de Paoli, M. M., Mills, E. A., \& Grønningsaeter, A. B. (2012). The ARV rollout and the disability grant: A South Africa dilemma? Journal of the International AIDS Society, 15(6), 1-10. https://doi.org/10.1186/17582652-15-6

DEAT [Department of Environmental Affairs and Tourism]. (2004). Ten-year review report. Retrieved from www.deat.gov.za

DED [Department of Economic Development]. (2011). Annual report 2010/11. Retrieved from http://www.gov.za/sites/default/files/gcis document/201409/edd-annual-report-20102011.pdf

DSBD [Department of Small Business Development]. (2014). Edited 2014 Review of small businesses in South Africa: Report for the Department of Small Business Development. Annual review of small businesses in South Africa 2007-2014. Retrieved from http://www.dsbd.gov.za/wp-content/uploads/2019/03/Final-2014SME-Review.pdf

DSBD [Department of Small Business Development]. (2020). COVID-19 emergency funding package. Retrieved from

http://www.gov.za/cdn.ymaws.com/www.thecdi.org.za/resource/resmgr/newsletter2020/covid_19_smme_su pport.pdf

DTI [Department of Trade and Industry]. (2005). Review of ten years of small business support in South Africa: 1994-2004. Retrieved from http://www.dti.gov.za/sme_development/docs/10 year_Review.pdf

DTI [Department of Trade and Industry]. (2012). South African handmade collection: An initiative of the DTI. Retrieved from http://www.thedti.gov.za/DownloadFileAction?id=697

Drucker, P. F. (1994). Theory of the business. Harvard Business Review. Retrieved from https://hbr.org/1994/09/the-theory-of-the-business

Dube, K., Nhamo, G., \& Chikodzi, D. (2021). COVID-19 cripples global restaurant and hospitality industry. Current Issues in Tourism, 24(11), 1487-1490. https://doi.org/10.1080/13683500.2020.1773416

Dzinamarira, T., Nachipo, B., Phiri, B., \& Musuka, G. (2021). COVID-19 vaccine roll-out in South Africa and Zimbabwe: Urgent need to address community preparedness, fears and hesitancy. Vaccines, 9(250), 1-10. https://doi.org/10.3390/vaccines 9030250

Gössling, S., Scott, D., \& Hall, C. M. (2020). Pandemics, tourism and global change: A rapid assessment of COVID-19. Journal of Sustainable Tourism, 29(1), 1-20. https://doi.org/10.1080/09669582.2020.1758708

Gregurec, I., Tomičić, F., \& Tomicic-Pupek, K. (2021). The impact of COVID-19 on sustainable business models in SMEs. Sustainability, 13(3), 1098. https://doi.org/10.3390/su13031098

Greve, N. (2014). New cabinet: Thinking small. Engineering News, 6-12 June, p. 11.

Haarhoff, R., \& De Klerk, B. (2019). Destination South Africa: Analysis of destination awareness and image by international visitors. GeoJournal of Tourism and Geosites, 24(1), 201-211. https://doi.org/10.30892/gtg.24116-353

Hlengwa, D. C., \& Thusi, K. (2018). Crucial for economic growth, nonetheless facing numerous challenges: Tourism SMMEs within uMsunduzi Local Municipality. African Journal of Hospitality, Tourism and Leisure, $7(1), 1-16$. 
Ikwegbue, P. C., Enaifoghe, A. O., Maduku, H., \& Agwuna, L. U. (2021). The challenges of COVID-19 pandemic and South Africa's response. African Renaissance, 18(1), 271-292. https://doi.org/10.31920/25165305/2021/18n1a13

Jamal, T., \& Budke, C. (2020). Tourism in a world with pandemics: Local-global responsibility in action. Journal of Tourism Futures, 6(2), 181-188. https://doi.org/10.1108/JTF-02-2020-0014

Joubert, L. (2020). Covid-19 gives tourism a 'snotklap': Lessons for a climate-altered future. Retrieved from https://www.dailymaverick.co.za/article/2020-04-03-covid-19-gives-tourism-a-snotklap-lessons-for-adclimate-altered-future.pdf

Jovanov Marjanova, T., \& Sofijanova, E. (2014). Corporate mission statement and business performance: Through the prism of Macedonian companies. Balkan Social Science Review, 3, 179-199.

Kaplan, L. (2004). Skills development in tourism: South Africa's tourism-led development strategy. GeoJournal, 60(3), 217-227. https://doi.org/10.1023/B:GEJO.0000034729.04687.a2

Kelliher, F. (2005). Interpretivism and the pursuit of research legitimisation: An integrated approach to single case design. The Electronic Journal of Business Research Methodology, 3(2), 123-132.

Khan, A., Bibi, S., Lyu, J., Latif, A., \& Lorenzo, A. (2021). COVID-19 and sectoral employment trends: Assessing resilience in US leisure and hospitality industry. Current Issues in Tourism, 24(7), 952-969. https://doi.org/10.1080/13683500.2020.1850653

Kollamparambil, U., \& Oyenubi, A. (2021). Behavioural response to the Covid-19 pandemic in South Africa. PLoS ONE, 16(4), 1-19. https://doi.org/10.1371/journal.pone.0250269

Mao, C. K., Ding, C. G., \& Lee, H. Y. (2010). Post-SARS tourist arrival recovery patterns: An analysis based on a catastrophe theory. Tourism Management, 31(6), 855-861. https://doi.org/10.1016/j.tourman.2009.03.003

Mariani, M. M., \& Giorgio, L. (2017). The 'Pink Night' festival revisited: Meta-events and the role of destination partnerships in staging event tourism. Annals of Tourism Research, 62, 89-109. https://doi.org/10.1016/j.annals.2016.11.003

Maritz, A., Perényi, Á., De Waal, G. A., \& Buck, C. (2020). Entrepreneurship as the unsung hero during the current COVID-19 economic crisis: Australian perspectives. Sustainability, 12, 4612. https://doi.org/10.3390/su12114612

Mshenga, P. M., \& Richardson, R. B. (2013). Micro and small enterprise participation in tourism in coastal Kenya. Small Business Economics, 41(3), 667-681. https://doi.org/10.1007/s11187-012-9449-5

Myeza, J., Mason, R. B., \& Peddemors, V. M. (2010). Socio-economic implications of the KwaZulu-Natal sardine run for local indigenous communities. African Journal of Marine Science, 32(2), 399-404. https://doi.org/10.2989/1814232X.2010.506991

National Planning Commission. (2011). National development plan: Vision for 2030. Pretoria: National Planning Commission. Retrieved from http://www.gov.za/sites/default/files/gcis_document/201409/devplan2.pdf

Nemasetoni, I., \& Rogerson, C. M. (2005). Developing small firms in township tourism: Emerging tour operators in Gauteng. Urban Forum, 16(2/3), 196-213. https://doi.org/10.1007/s12132-005-1005-9

Neuburger, L., \& Egger, R. (2021). Travel risk perception and travel behaviour during the COVID-19 pandemic 2020: A case study of the DACH region. Current Issues in Tourism, 24(7), 1003-1016. https://doi.org/10.1080/13683500.2020.1803807

Norris, F. H., Stevens, S. P., Pfefferbaum, B., Wyche, K. F., \& Pfefferbaum, R. L. (2008). Community resilience as a metaphor, theory, set of capacities, and strategy for disaster readiness. American Journal of Community Psychology, 41(1-2), 127-150. https://doi.org/10.1007/s10464-007-9156-6

Ntounis, N., Parker, C., Skinner, H., Steadman, C., \& Warnaby, G. (2021). Tourism and hospitality industry resilience during the Covid-19 pandemic: Evidence from England. Current Issues in Tourism. https://doi.org/10.1080/13683500.2021.1883556

Odeku, K. O. (2020). The plight of women entrepreneur during COVID-19 pandemic lockdown in South Africa. Gender \& Behaviour, 18(3), 16068-16074.

Pennington-Gray, L., Schroeder, A., \& Kaplanidou, K. K. (2011). Examining the influence of past travel experience, general web searching behaviour and risk perception on future travel intentions. International Journal of Safety and Security in Tourism, 1(1), 64-92. 
Ramukumba, T. (2019). An evaluation of festival activities as motives for festival attendance: A case study of strawberry festival at the Redberry Farm in George, South Africa. African Journal of Hospitality, Tourism and Leisure, 6(4), 1-12.

Ray Nkonyeni Municipality. (2016/17). Final integrated development plan. Retrieved fromhttp://rnm.gov.za/HCM_Documents/IDP/Final\%202017-2022.pdf

Rigby, D. (2011). Marketing: The future of shopping. Harvard Business Review, 89(12), 1-12.

Ritchie, B., \& Jiang, Y. (2019). A review of research on tourism risk, crisis and disaster management: launching the annals of tourism research curated collection on tourism risk, crisis and disaster management. Annals of Tourism Research, 79, 102812. https://doi.org/10.1016/j.annals.2019.102812

Rogan, M., \& Skinner, C. (2020). The Covid-19 crisis and the South African informal economy 'locked out'of livelihoods and employment: National income dynamics study (NIDS): Coronavirus rapid mobile survey (CRAM). Retrieved from https://cramsurvey.org/wpcontent/uploads/2020/07/Rogan-Covid-crisis-and-theSouth-African-informal-economy.pdf

Rogerson, C. M. (2005). Unpacking tourism SMMEs in South Africa: Structure, support, needs and policy response. Development Southern Africa, 25(5), 623-642. https://doi.org/10.1080/03768350500364224

Rogerson, C. M., \& Rogerson, J. M. (2020). COVID-19 tourism impacts in South Africa: Government and industry responses. Geojournal of Tourism and Geosites, 31(3), 1083-1091. https://doi.org/10.30892/gtg.31321-544

Rogerson, C. M., \& Rogerson, J. M. (2021). COVID-19 and changing tourism demand: Research review and policy implications for South Africa. African Journal of Hospitality, Tourism and Leisure, 10(1), 1-21. https://doi.org/10.46222/ajhtl.19770720-83

Rogerson, J. M., Lekgau, R. J., Mashapa, M. M., \& Rogerson, C. M. (2021). Covid-19 and local business responses: Evidence from South Africa's most tourism-dependent locality. African Journal of Hospitality, Tourism and Leisure, 10(1), 388-405. https://doi.org/10.46222/ajhtl.19770720-107

Ruiz-Martin, C., López-Paredes, A., \& Wainer, G. (2018). What we know and do not know about organizational resilience. International Journal of Production Management and Engineering, 6(1), 11-28. https://doi.org/10.4995/ijpme.2018.7898

Smith, J. A. (2010). Evaluating the contribution of interpretative phenomenological analysis. Health Psychology Review, 5(1), 9-27. https://doi.org/10.1080/17437199.2010.510659

South African Government. (2021). Let's grow South Africa together. Retrieved from www.gov.za/coronavirus/alert-level-2.pdf

Speakman, M., \& Sharpley, R. (2012). A chaos theory perspective on destination crisis management: Evidence from Mexico. Journal of Destination Marketing \& Management, 1, 67-77. https://doi.org/10.1016/j.jdmm.2012.05.003

StatsSA [Statistics South Africa]. (2019). Statistical Release: Tourism and Migration. Retrieved from https://www.statssa.gov.za/publications/P0351/P0351February2019.pdf

StatsSA [Statistics South Africa]. (2021). Quarterly Labour Force Survey (QLFS) Q2: 2021. Retrieved from www.statssa.gov.za/publications/P0211/Presentation\%20QLFS\%20Q2_2021.pdf

Sutton, J., \& Austin, Z. (2015). Qualitative research: Data collection, analysis, and management. Retrieved from https://www.ncbi.nlm.nih.gov/pmc/articles/PMC4485510.pdf

Taylor Jr, S. (2020). The socially distant servicescape: An investigation of consumer preference's during the reopening phase. International Journal of Hospitality Management, 91, 102692. https://doi.org/10.1016/j.ijhm.2020.102692

UN [United Nations]. (2002). World summit on sustainable development. Johannesburg. Retrieved from https://www.johannesburg.org

UNWTO [United Nations World Tourism Organization]. (2020). International tourism arrivals could fall by 20$30 \%$ in 2020. Retrieved from https:/www.unwto.org/news/international-tourism-arrivals-could-fallin2020.pdf

Weinstein, N. (1988). The precaution adoption process. Health Psychology, 7(4), 355-386. https://doi.org/10.1037//0278-6133.7.4.355

WHO [World Health Organization]. (2015). WHO strategic response plan: West Africa Ebola outbreak. Retrieved 
from http://www.who.int

WHO [World Health Organization]. (2020). WHO coronavirus disease (COVID-19) dashboard. From: World Health Organization. Retrieved from https://covid19.who.int/info

WTTC [World Travel \& Tourism Council]. (2020). Travel \& tourism economic impact 2017, South Africa. Retrieved from https://wttc.org/Research/Economic/Impact.pdf

\section{Copyrights}

Copyright for this article is retained by the author(s), with first publication rights granted to the journal.

This is an open-access article distributed under the terms and conditions of the Creative Commons Attribution license (http://creativecommons.org/licenses/by/4.0/). 